\title{
Performing Presence with the Teaching-Body via Videoconferencing: A Postdigital Study of the Teacher's Face and Voice
}

\section{Yi Wei Chew ${ }^{1}$ (D)}

Accepted: 14 January 2022 / Published online: 25 February 2022

(c) The Author(s), under exclusive licence to Springer Nature Switzerland AG 2022

\begin{abstract}
This paper addresses the dearth in research on embodied teaching by focusing on the body of the teacher, in particular their face, voice, use of silence, and their relationship with presence online. Postdigital positioning of the notion and experience of embodiment online posits a dynamic co-existence between technology and all aspects of human life including that which is social, physical, and material. Based on interviews conducted with five lecturers in different disciplines at a university in Singapore, and using the theoretical lens of Performance Studies, this paper presents an explanatory study that argues for the synergistic relationship between the teaching-body, presence, in/and online videoconferencing within the postdigital context. It argues that teaching presence takes place online and that the teachingbody is central to the performance of presence leading to a more meaningful educational experience.
\end{abstract}

Keywords Postdigital $\cdot$ Teaching-body $\cdot$ Presence $\cdot$ Performativity $\cdot$ Face $\cdot$ Voice $\cdot$ Silence

\section{Introduction}

Education scholars whose research focuses on embodiment often advocate pivoting away from Newton's western-centric idea of cogito ergo sum towards a more multidimensional, humanistic understanding of learning and teaching-which includes not just the mind but the individual's body and emotions as well. Consequently, many articles have been published on the body of the learner, and how it contributes to the learning process both online and onsite, synchronously and asynchronously (Barbour 2004; Ellsworth 2004; Kelland 2006; Freiler 2008; Glenberg 2009;

Yi Wei Chew

sharleenchewyw@suss.edu.sg

1 Singapore University of Social Sciences, Teaching and Learning Centre, 463, Clementi Road 599494, Singapore 
Perry and Medina 2011; Francesconi and Tarrozi 2012; Tobin and Tisdell 2015; Rigg 2018; Leigh 2019; Öztok and Brett 2011). ${ }^{1}$ Less, however, has been said on the teacher's body (Probyn 2004; Bolldén 2014). This gap in scholarship calls for a more systematized, concrete move to recognize and re-experience directly the teacher's body and its centrality in/to pedagogy, curriculum, and assessment.

I quote Chris Shilling at length here for his elucidation on the place of the body in academia, everyday life, and humanity:

The importance of the body goes beyond abstract philosophical formulations ... irrespective of how provocative or impressive these may be. Our embodied existence can be seen as a foundation from which can be built an empirically informed yet distinctive approach to the analysis of society, identity, culture, and history. At its most basic, this involves recognizing that people's ability to make a difference to their own lives, and to those of others, depends on them being, having, and using their bodies in order to intervene in the 'flow' of social life. $(2016: 3)^{2}$

Following Schilling, this paper is premised on the intellectual and existential commitment to the body in academic discourse writ large. This paper addresses the dearth in research on embodied teaching by focusing particularly on the body of the teacher, or what I refer to as the 'teaching-body,' and its relationship with presence in online synchronous videoconferencing lessons.

I use the hyphenated phrasal noun 'teaching-body' to signify the body of the teacher. The intention of giving the teacher's body a name underscores both its semantic and symbolic significance: 'Teaching' is employed both as a verb and an adjective to describe a body that not only belongs to the teacher, but a body that teaches (i.e., that carries out the act(ion) of teaching). The hyphen further implies the continuity and inextricable connection between the teacher, their body, and the fact that their body is a site of/for teaching.

While the paper focuses on synchronous videoconferencing lessons, it should be acknowledged that online education can also take place asynchronously; there is no need for actual contact time between instructors and students for teaching and learning to take place (Munoz and Towner 2009; Selwyn 2012). It cannot be assumed that there is little or no teaching-presence at all in asynchronous online classrooms (Shea et al. 2005; Preisman 2014); that the teacher does not have a digital identity (Sime and Themelis 2020); and/or that the teaching-body is completely absent.

Teaching-presence can, for example, manifest itself should the teacher upload photographs or images of himself/herself (Rosati-Peterson et al. 2021). Similarly, the written instructions and assessments the teacher posts online-qua the performative textuality of the written text (Pollock 1998, 2007; Stacey 2002; Sundén 2003)— are indicative of teaching-presence as well.

\footnotetext{
${ }^{1}$ Merleau-Ponty is often mentioned in education scholarship on the place of the body in learning and teaching (Alerby, Hagström, and Westman 2014; Ward 2018).

${ }^{2}$ For more on Shilling's seminal works on the body, refer to Schilling (2012) and Schilling (2020).
} 
Electronic devices like phones and laptops play an indispensable role in facilitating such interactions together with broadband connection. A coming together of online classroom participants (teacher and students), their material digital devices, software, fiber optical waves, as well as human interaction-all of which contribute to presence-making in asynchronous (and indeed synchronous) online classrooms-is hence evident. 'In the broadest sense [then,] materiality emerges from the dynamic interplay between the richness of a physically robust world and human intelligence as it crafts this physicality to create meaning' (Hayles 2002: 32-33) and online presence.

Considering the above arguments, a critical response to Hubert Dreyfus' (2001) traditionalist notion of presence as being possible only in physical environments is necessary if we were to examine presence in online environments both synchronously and asynchronously. His view maintains that interactions between teacher/s and student/s, or any two human beings for that matter are best and only achievable when they are physically together in a shared space:

Two human beings conversing face to face depend on a subtle combination of eye movements, head motion, gesture and posture and so interact in a much richer way than most roboticists realize ... a holistic sense of embodied interaction may well be crucial to everyday human encounters, and that this intercorporeality ... cannot be captured by adding together 3D images, stereo sound, remote control, and so forth. (Dreyfus 2001: 56)

Seemingly proving Dreyfus right, there exist areas of research suggesting that 'conversing face to face' in a shared physical space remains the preferred mode for teachers and students as compared to interacting online or in virtual environmentsespecially so when it pertains to how presence is understood and experienced (Lehman and Conceição 2010; Muthuprasad et al. 2021). Lehman and Conceição (2010) suggest that students and educators still view the digital to be by default disembodied and non-material and that it does not 'involve the body [and hence] the "person", in the sense of doing something "in person", (Gourlay 2021: 58) within a particular physical space. This also indicates that relevant electronic devices like laptops, smart phones, tablets, and routers and modems are assumed to exist separately from the online environment or that they play merely an operational role in the online classroom.

However, as researchers and educators living in the present Zeitgeist where virtual teaching and learning is necessary, and perhaps inevitable, we need to challenge the mindsets, attitudes, and habits that contribute to the ongoing preference for the physical classroom. Critiques on this view have already been done by the likes of Bayne (2004), Selwyn (2016). Bayne and Jandrić (2017), Fawns (2019), Fawns et al. (2019), Jandrić and Hayes (2020), as well as Gourlay (2020, 2021), all of whom posit a less parochial view towards the relationship between human beings, education, technology, spatiality, socio-materiality, and embodiment. By building on their research, and more importantly appreciating their philosophies on education and technology, we will be able to improve and innovate on our teaching practices as we enter an age where education, the human being, and the digital cannot but co-exist. 
This paper does not seek to debunk Dreyfus' (2001) ideas. Rather, it urges educators and researchers to reconsider their relationships with teaching via videoconferencing, with a view to creating a more engaging and meaningful educational experience.

\section{Postdigital 'Meaningful Educational Experience'}

What counts as 'meaningful educational experience' in today's context? I approach this question from the postdigital perspective-a position I find accurate, practical, and intellectually robust. The postdigital perspective states that 'the digital is not a special or separate domain from embodied, co-present spaces that we inhabit day to day - instead, the two kinds of spaces are inextricably linked with each other' (Bayne and Jandrić 2017: 198-199) (emphasis added). This underscores that technology is interminably part of 'the flow of social life' (Schilling 2016: 3), social reality, and experience. Guided by this logic, it is no longer tenable that technology, embodiment, and space are viewed as separately functioning entities. To date, there have been very laudable efforts by scholars to engage the body in digital environments within the educational context (Land 2004; Kelland 2006; Casey and Kroth 2013; Bolldén 2014; Kennette and Redd 2015). Be that as it may, what remains conspicuously missing from their research is the idea of the postdigital.

Rather than adopt a stance against the use of technology as per Dreyfus (2001), the postdigital perspective offers us the opportunity to understand and apply the technologies available to us with our bodies along with the physical and virtual spaces in which we inhabit. They work and co-exist as a triptych that enables us to see the metaphorical big picture: a socio-material dynamic that is "neither online nor offline but distributed between learner, teacher and social, material and digital world. Learning spills out beyond the classroom and the computer, blending face-toface and online, asynchronous and synchronous, bodily and cognitive forms' (Fawns 2019: 134). The postdigital perspective also takes as a given the inherently social nature of education (Dewey 1961, 2000) where the body is always already part of the classroom's social dynamics, online or not. Presence in the online environment is consequently no less embodied than it is onsite.

By this token, online learning and teaching do not only happen online; they remain corporeal, embodied, seeping from the virtual learning environment across, and (Fawns and O'Shea 2019) 'into the physical settings of home, cafes, and workplaces and in transit between them' (Fawns et al. 2019: 294). Jandrić and Hayes encapsulate the postdigital ethos most elegantly and eloquently by calling it a 'gathering between humans and machines' (2020: 285) where we 'draw on all of these technologies as integral to our lives and the lives of others, and to question who and what humans and intelligences really are, in [a] shared context' (2020: 295) (emphasis added).

This article seeks not to find solutions nor formulate new theories. Rather, it presents an exploratory study aimed at opening new and expanded vistas of scholarship into how and why presence and the body of the teacher should be understood and applied in postdigital education in a postdigital world - a fledgling but growing area of research and praxis that holds much promise for both academics and practitioners alike. 


\section{Presence, Performance, and Performativity}

'Presence describes the ways in which human beings interact with each other' (Casey and Kroth 2013: 104), or 'a sense of being there or being together' (Lehman and Conceição 2010: 3). That the synonymous phrases 'each other' and 'being together' are mentioned in both definitions implies that presence must be understood as a phenomenon that is at once social and dialogic. Applying this to education, presence is 'a state of alert awareness, receptivity, and connectedness to the mental, emotional, and physical workings of both the individual and the group in the context of their learning environments, and the ability to respond with a considered and compassionate best next step' (Rodgers and Raider-Roth 2006: 265) (emphasis added).

Teaching-presence and student presence must never be seen as mutually exclusive, but always already interconnected. In this sense, presence within a classroom is an organic exchange that is never static. It is an exchange that involves not just teachers and their bodies, but the way students feel and act in response to their teacher's presence and vice versa. This paper's focus on the teaching-body and its performing of teaching-presence does not omit nor downplay the reality of student presence. Instead, it builds on the acknowledgement that presence, despite its elusive, unquantifiable nature, is and remains essential to teaching (Rodgers and Raider-Roth 2006; Kennette and Redd 2015). It is the response of teachers to their students, and the ways in which teaching-presence is generated by teaching-bodies, that is committed to deeper study.

It is noteworthy that Rodgers and Raider Roth (2006) mention the idea of the 'physical.' Prima facie, presence is relevant only in physical settings where physical bodies are present. Given the pervasiveness of technology and the Internet in education since the cusp of the twenty-first century however, scholars have begun to re-evaluate and extend their understanding of presence to the online environment (Anderson et al. 2001; Ijsselsteijn and Riva 2003; Lehman and Conceição 2010; Kennette and Redd 2015). As Christine Hine (2015: 24) observes: 'How the Internet is embedded into our lives is in part a product of an embodied engagement with the Internet, and in turn, of course, the Internet can shape our experience of embodiment as the information and insights we find online help us to understand ourselves in new ways.'

Following Hine, we could expand what Rodgers and Raider-Roth (2006) posit by re-conceiving 'physical workings' and presence to include not just what happens physically in an onsite classroom, but what happens physically online as well. This expansion of discourse on presence is even more critical if we are to address student complaints that presence is not felt as much online as it is in a physical classroom (Biocca et al. 2003; Lehman and Conceição 2010). In response to these grievances, what needs to be further developed is the role the teaching-body plays in both the creating and performing of presence in online environments within a postdigital educational context. It is a welcome shift therefore that scholars in the field of education like Jandric and Hayes (2020) and Fawns et al. (2019) are finally re-examining the body and its relation to presence. By building on their ideas, I further develop the ways in which presence and the teaching-body can be understood by taking an interdisciplinary view. 
The body is a much discussed, highly theorized, and applied area of Performance Studies; one cannot possibly talk about performance without bringing in the body (Clarke and Davidson 1998; Green 1999; Campbell 2000; Conroy 2010; Suzuki 2015; Jarvis 2019; Evans 2019). As such, Performance Studies presents strong theoretical grounding on what it means to be embodied, and how our bodies help us make sense of the world. Performance Studies is not just limited to theatre, dance, and music. It seeks, in fact, to include the many other activities carried out in everyday life such as politics, religion, and even ordinary face-to-face interactions (Schechner 2007), and not least education-all of which are everyday cultural practices occurring within a particular socio-cultural context (Tiberius and Billson 1991; Edwards-Groves 2017; Mardahl-Hansen 2018) that always already involve the body.

The performance paradigm has enabled a dialogue between Performance Studies and educational theory, developing a 'language of possibility' for both disciplines (Pineau 2004: 36). Indeed, these possibilities are not just limited to the ways in which we write about educational theory and practice; they also extend into the epistemologies and application of classroom practices and interactions.

The classroom, with teachers and students engaged in the processes of education ... becomes a practiced place; a site in which diverse beings [with their bodies] come together in order to engage and negotiate knowledge, systems of understanding, and ways of being, seeing, knowing, and doing. This negotiation occurs through social performance; engaged [embodied] practices of relations and interrelations. (Alexander et al. 2004: 3)

Teaching is a social activity or 'performance' that happens as part of everyday life where teachers and students are embodied social actors emplaced in their specific built as well as virtual environments.

Heeding the call towards adopting Performance Studies as a theoretical lens through which we can better understand education, this study presupposes that teaching is performance as well as performative, with the latter 'denot[ing] modes of presenting or evoking action' (Burns 2009: 370) within a specific material, embodied, and socio-cultural context. Performativity refers to teaching as 'doing', but it is also the repetitive act of doing that manifests its existential and practical presence (Alexander et al. 2004: 4). In other words, the act of teaching never exists in and of itself. It is performative of its embodied (e.g. racial, gendered), political, socio-cultural, socio-material, spatial, and physical structures. To understand what teaching is performative of, we must approach it through cultural analysis of teacher's bodies and teaching behaviors (Schechner 2007).

This research does not seek reified conclusions about the teaching-body and presence. Rather, it explores the role of the teaching-body in generating teachingpresence qua the teacher's face, voice, and silence in online synchronous videoconferencing lessons. I posit that teaching-presence is performed by the teaching-body and that its performativity points to the teaching-body as the site of pedagogical design and delivery. The teaching-body's intersections with the postdigital will also be considered through which a more meaningful educational experience can be achieved. 


\section{Methodology}

Zoom $^{3}$ was used for the purpose of teaching and for the conducting of interviews. Yet this paper does not analyze Zoom per se, nor does it privilege it over any other videoconferencing platform. Zoom was used simply because social in-person gatherings were limited due to Covid-19 restrictions, and it happens to be the primary videoconferencing platform at my institution. The study may not have differed should I have used any other videoconferencing platform.

Zoom interviews were conducted with five lecturers from the same university, with each of them coming from different disciplines: Lecturer One teaches Law, Lecturer Two Marketing, Lecturer Three Leadership and Human Resource, Lecturer Four Philosophy (as part of the University's Core Curriculum), and Lecturer Five Counselling. Each interview lasted between sixty to ninety minutes.

A list of questions was shown to each participant during the interview. The questions were sectioned according to two broad topics, bearing in mind the imbrications between them:

Section 1: Firsthand experience of instructor presence while teaching.

Section 2: Technology and the body in/when teaching.

Questions in both sections were deliberately given a phenomenological quality. Sample questions include the following:

- What does the embodiment mean to you as per your experience? Describe.

- Describe your experience of teaching in-person?

- Describe your experience of teaching via videoconferencing

- Describe the relationship you (and your body) have with technology.

o Describe how you feel about it.

The questions are phrased in an open-ended manner to allow for a spectrum of answers relative to the interviewees' own classroom experience. This enabled participants to describe their firsthand experiences of presence, while they were teaching onsite and online. Experiences were therefore articulated as they were without the filter of intellectualization (Natanson 1973; Husserl 1983). It was also imperative to discuss the use of technology - the interaction between teaching-bodies and videoconferencing platforms_-and how that affected the performing and performativity of teaching-presence.

The interviews were not merely set out as standard Question and Answer sessions, but ones that also involved conversation. Interviews are social interactions based on conversations between researcher and participants, which further enable the co-construction of knowledge between the parties (Rubin and Rubin 1995; Warren and Xavia Karner 2015; Brinkmann and Kvale 2015). The conversational quality of each interview engendered a spontaneity which added to the co-construction of knowledge.

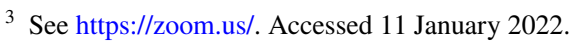


All five interviews were recorded using the video and audio functions. The video recording and the audio served as written, audio, and visual empirical data which I transcribed by reading the audio transcripts while listening to the recordings. The transcription process allowed me to sieve out significant ideas articulated by the participants. I condensed these ideas into categories, which were then distilled into themes. In thematic analysis (Guest et al. 2012; Lochmiller 2021; Hernandez and Dringus 2021), I applied the following coding categories as recommended by Vaismoradi and colleagues:

- The conceptual code with 'key elements, domains and dimensions of the study phenomenon'.

- The relationship code with 'links between elements, domains and dimensions'.

- The participant perspective code with 'the participant's positive, negative, or indifferent comments about a particular experience' (Vaismoradi et al. 2016: 103).

These categories present links between theories and participant attitudes. They also aid in a structured but interconnected analysis of data, as well as the formulation of meaning and their associated themes (see Appendix).

\section{Findings and Discussion}

Data analysis resulted in two themes: face and voice/silence as parts of teachingbodies in the performing of teaching-presence. Participants focused primarily on how being seen and heard on Zoom was essential to their practice when conducting online classes. Participants' discussion of face and voice led to a dialogic discourse with a lot of mutual agreement between the interviewer and the interviewees. These shared experiences add to the co-construction of knowledge and the interpretation of data, reinforcing the viability of the generated themes.

\section{Theme 1: The Role of the Teacher's Face in Performing Teaching-Presence}

In the context of an online lesson via videoconferencing platforms, it is expected that the teacher switches on their camera. By doing so, the teacher's body-their teaching-body of which their face is a part-is usually visible from chest up. Such a posture renders the teacher to be actually and physically 'talking to the screen' (Gourlay 2021: 58), with their face as the most prominent and enduring fixture. Therefore, videoconferencing exchanges are literally face-to-face.

This expands traditional understandings of the term 'face-to-face,' and such expansion also changes the performativity of what we linguistically label, identify, and associate with the term. '[L]anguage develops in tune with the society of which it is the language. The social habits of the society may considerably affect the question of which performative verbs are evolved' (Austin 1979: 245). At present, the 
utterance of 'face-to-face' performs our techno-social bias towards onsite, physical settings, rejecting face on the screen, which is reductively seen as a mediated image. However, as per Austin (1979), a shift in the way we understand the current linguistic signifier of 'face-to-face' will shift its performativity to a new kind of 'doing'. By adopting a postdigital logic in understanding the face-on-screen, we will aid in the reconceptualization and experience of our current techno-social prejudices. A face is a face, online and offline. Online face is seen with the aid of the screen and the Internet, yet it is not being mitigated or compromised. It is thus a misnomer that only onsite interactions are synonymously referred to as being 'face-to-face'.

Given its physical prominence and centrality, what is the performativity of face in everyday social interactions (including teaching)?

Face is not just a physical part of the body. It performs 'an image of self, delineated in terms of approved social attributes' (Goffman 1967: 5). We 'experience an immediate emotional response to the face which a contact with others allows [us]; [we] cathect our faces. [Our] feelings become attached to it' (1967: 6). Given its constant appearance, size (equivalent to that of a close-up or a medium close-up), and its remaining mostly in one position, a face seen on a videoconferencing platform can be significantly more palpable, its communicative cues more pronounced, as compared to a face seen in a physical classroom.

Lecturer One is especially mindful of his face as he knows that the way he appears to his students is always already a dialogic exchange and will subsequently and consequently influence classroom dynamics, teacher-student interaction, and learning of content. He admits therefore to 'soften[ing] [his] facial features' when he speaks to his students, while 'maintaining eye contact' with them. Expounding further, he says: 'In an online class, I have a habit of speaking into the camera quite purposefully when I'm making a point.' He does this so that students know that he is focusing on them and looking directly at them even though they are not physically in the same space. He creates visual proximity using his face, performing a presence that is at once intimate and ineluctable.

His face and the teaching-presence it generates are performative because ofnot in spite of - the screen. The cathecting of his face on screen performs a convergence of the socio-material, physical, and technological: lecturer's and his students' engagement with each other via their physical devices. The physical face needs the screen in order to distribute teaching-presence-one cannot exist without the other.

Similarly, Lecturer Four ensures that she dresses up for the teaching event. Unlike many users of videoconferencing platforms who appreciate that they can work without having to dress up (Hacker et al. 2020), she is unapologetic about the need to look professional even when all her students can see of her is from the chest up. 'I actually do make-up, like wear my lipstick and wear my earrings because I think [students] still need to know that I am there, my presence is very formal.' In return, she receives feedback from her students thanking her for her efforts to dress up not only for the lesson, but for them as well. "They did notice and said "oh, we were wondering what color code you are wearing this week". It is nice occasionally when they mention this ... It means they appreciate my presence and my consideration of them.' Looking professional is being professional, even though dressing up teaching 
online in real time is not mandatory when. Lecturer Four's face performs a presence that is at once 'formal,' professional, and congenial.

Making the effort to dress up extends home space into online classroom space. Lecturer Four performs her teaching presence qua the transformation of her domestic space into that of the classroom. Her adorned face-the face that typically performs the everyday routine of going to actual workplace-therefore renders boundaries between the teaching-body's physical domestic space and that of the virtual space to be no longer distinct. Here, we witness a dynamic coexistence between technology, the built environment, and the virtual space-in real, synchronous time-coming into an intersection where the social, physical, and material engage in a postdigital co-mingling.

In both examples, teachers' faces perform a presence that is highly aware and sensitive to the way students perceive them and respond to them. Students pick up the visual cues of Lecturer One and Lecturer Four's faces and react to them feeling that they matter to their lecturers not just academically, but relationally and affectively. To both lecturers, the face is inescapably the site of unmediated intimacy and professionalism.

The performance of presence in response to the social dynamics of the group is magnified by the lecturers' ability to look at themselves. This feature, present in all videoconferencing systems, allows lecturers to become their own audience, causing them to be more conscious of how they look as they interact with their students. As Lecturer One says that he is always 'halfway between looking at the camera and looking at the facial expressions' of the students. He checks himself to see if his facial expressions are in concert with his students' learning and how they might be feeling. According to Goffman (1967: 6), '[o]ne's own face and the face of others are constructs of the same order; it is the rules of the group and the definition of the situation which determine how much feeling one is to have for face and how this feeling is to be distributed among the faces involved.'

The softening of Lecturer One's facial features and Lecturer Four dressing up for the lesson are performative of the social value of their students' facesreticence, uncertainty, congeniality, and respect. They perform teaching-presence with their faces by 'distributing' an emotional presence appropriate to the group dynamics of their classes. The ability to see themselves illustrates the relationship between the screen and the teaching-body. The teaching-body behind the screen is constantly engaging not only with their students but with the image of their face. While the teacher cathects their face to create teaching presence for their students, they concurrently have to negotiate with the images of themselves.

The image of the teacher on screen becomes their audience, engendering the creation of a virtual self, and hence another visible online identity along with the physical, dialogic self (Jonassen 2000; Walters and Kop 2009) The physical teaching-body behind the screen looking at the one on screen performs a material and virtual teaching-presence that is self-reflective and reflexive; one that can be seen and felt materially. The confluence of both selves allows the teaching-body to adapt accordingly to student responses, as well as respond to the image of himself/ 
herself. ${ }^{4}$ Lecturer One being able to see his virtual self enables him to become his own audience, and as such, he experiences his own teaching-presence from the space of his home.

When teachers become self-conscious and distracted by looking back at an image of themselves, this may potentially result in a cathexis that fails to distribute teaching-presence amongst their students and hence compromise on how present they can be in online synchronous space. None of the participants reported feeling this way however, not least Lecturer One who is able to look at himself and at his students and concomitantly manage both his face and theirs. Teachers are perhaps not distracted because they appear merely as a 'thumbnail' while screen-sharing their PowerPoint slides for most of the lesson. All five lecturers describe the thumbnail feature to be too diminutive to elicit much of a distraction, if at all.

A postdigital interaction takes place between the computer, the image of teachingbody on screen and outside of it, as the teacher inhabits their physical space-all of which are necessary in the performing of teaching-presence.

\section{Theme 2: The Role of the Teacher's Voice and Silence in Performing Teaching-Presence}

'Simultaneously tied to the body [and hence face] and entwined with the external environment, the voice exists in a complex interaction with multiple physical and sociocultural formations' (Schlichter and Eidsheim 2014: Para. 1). ${ }^{5}$ Understanding the voice as an embodied entity (Koivunen 2007; ParaTheatrical ReSearch 2008) provides a concatenation between the voice and the face, both of which are part of the teaching-body.

Lecturer One asserts that 'voice is an extension of the body,' as it requires the teaching-body - the vocal cords of the teacher-to come into being. As such, recognizing and endowing the voice as a legitimate site of study questions the tendency towards scopophilia where 'vision is the royal register of both understanding and action' (Pettman 2017: 2). The privileging of seeing is evident in online environments as per lecturers' emphasis on face. As such, approaching voice and silence as entities that exist in tandem with the seen/unseen face will enable a fuller insight into how the teaching-body is and can be used to perform presence in the videoconferencing classroom.

Voice can be understood physically and figuratively when we parse the word in the context of 'giving someone a voice' to mean the act of empowering. But what happens when presence is performed through the (audible) voice? What does the voice perform; what is its performativity? 'A focus on voice as ... performative means that the content as well as the form of voice must be considered

\footnotetext{
4 This self-consciousness and performance of face is of course also possible in social situations that do not involve the person literally looking at themself. Teaching in an onsite class, for example, also requires the teaching-body to consider how they maintain their face.

5 The teacher's voice has also been discussed by (McDonald 1986; Assor et al. 2009; Lyberg-Åhlander et al. 2014).
} 
in representation and participation' (Lawy 2017: 193) (emphasis added). It not just what is said, but how it is said that draws out the performativity of the voice.

Lecturer One is acutely aware of the role of the voice in creating presence: 'Your voice and the projection of it, they are very important to creating presence.' To him, both form (how something is said; sound, intonation) and content (what is said) are of equal heft. What is communicated is inextricably tied to the way it is communicated, even more so in an online environment where the voice is sometimes the only thing that is not just heard but felt.

The voice, with its materiality and 'feltness,' carries a meaning of its own (Schlichter and Eidsheim 2014: Para. 3). The voice should therefore be examined as an amalgam of the material, symbolic, and cultural in proffering meaning. Lecturer One explains: 'How do I engage students? ... In terms of the voice when I face a student who tends to be maybe a little shy or reticent or diffident, I would tend to slow down a little more, and my voice will be lowered a little more as well.' The materiality of his voice, modulated by his vocal cords, is not distinct from the socio-cultural demands of his lessons. ${ }^{6}$ Lecturer One uses his voice-its sound, pace, volume, and tone- to speak individually to the reserved student in question. At the same time, he knows that he is being heard by the rest of the class.

Lecturer Two admits to not giving too much thought about her body and voice while she teaches. 'I think it's just uh ... your body just is part of the environment. But again, in teaching, at least for me, I focus so much on the content itself, so I seldom think about myself and my own body.' Nevertheless, she uses her voice aggressively and intentionally during her lessons. 'At the beginning of online teaching, you just don't want to have empty spaces right, so if there are some minutes in between, it is very quiet ... you're afraid that you may lose your students, so you have to keep talking for the entire session.' Lecturer Three offers a similar lament: 'Because our students don't share their video, I obviously feel like (sic) when I'm speaking, it's almost like speaking to empty space.'

Both lecturers use the phrase 'empty space' and indicate strong reliance on their voices in ensuring that they do not 'lose' their students to inattentiveness or protracted silence. Their audible voices make up for being unable to see their students; they fill the 'empty space' of silence with teacher-talk. Under the circumstances, quietness and invisibility of students are experienced synonymously. Lecturers Two and Three therefore ensure that they are always present by paying attention, talking to, and listening to the 'empty space' made up of muted microphones and switched off cameras.

Furthermore, Lecturers Three and Five use the word 'energy' to describe presence. The former elaborates that energy is both 'physical and emotional' and that teaching involves a mutual 'giv[ing] out' and 'get[ting] back' of energy. Presence to her is therefore a relational, embodied, and affective experience that cannot be intellectualized nor individualized. Similarly, Lecturer Five describes presence as an 'exchange of energies' where 'in a teaching context ... there is actual interaction both ways.'

\footnotetext{
${ }^{6}$ Like most Asian students, Singaporean students are known to be deferential towards authority and taciturn when it comes to speaking up in the classroom (Tani 2004; Lee 2014).
} 
From a Performance Studies perspective, the actor also heavily relies on voice to create presence. Presence, according to Patsy Rodenburg, is the generation of energy; she enables her students 'to find their true energy and [reinforces to them that] this true energy [is] their presence' (Rodenburg 2007: xiii in McAllister-Viel 2016). Rosenburg's work is applicable to how teaching-presence can be discovered, understood, and performed qua the voice. Therefore, it is hardly a coincidence that the idea of 'energy' is brought up intuitively by Lecturers Three and Five. Albeit not mentioned explicitly, it is suggested by both lecturers that the use of voice is an ineradicable part of the interchange of energies and hence the creation and maintaining of their teaching-presence.

This energy transfer is multidirectional and depends on how energy is received and reproduced. Mutual exchanges of energy also require that the body and voice are situated in the present, in the 'here and now' (Rodenberg 2002: 226)—where the teaching-body is attendant and attentive to the immediate social dynamics of online videoconferencing class. The teaching-body is also a talking-body that projects an audible voice in order that energy is generated, and presence performed. Yet, while teacher-talk is common, and indeed needful practice in the videoconferencing classroom, what is often (mis)perceived as the opposite of sound, speech, and voice should also be considered-silence.

' $[$ S]ilence is not the absence of something but the presence of everything ... It is the presence of time, undisturbed' (Hempton 2009: 2). Study participants acknowledge the awkwardness and risk of silence in a videoconferencing class, often exacerbated by switched off cameras and microphones. How can silence become a kind of voice that is purposefully projected or prolonged by the teaching-body? How is it experienced physically in the online environment? What does silence perform?

Lecturer Four says: 'I tend to use ... silence ... So when I do that, [students] have to pay attention ... Silence helps a lot because silence also means it is serious right?' Instead of using her spoken voice to retain the attention of her students like Lecturers Two and Three, Lecturer Four uses silence. Here, we see the uneasy but productive weight of silence borne by her students when she stops talking. Clearly, 'sound creates subjectivity through its own surplus as much as absence' (Pettman 2017: 1). Lecturer Four's voice of silence becomes her teaching-presence that is heard and felt as a kind of gravitas signaling to students that they might be called to unmute and contribute randomly and at any moment. They feel her presence and thus use the enforced silence as a time for active thought and reflection.

Silence can also be used in a shared physical space. However, when experienced co-locationally and online, teacher's deliberate and constructed silence becomes more audible, reverberating into the earpieces/speakers of each student, gradually engulfing their individual physical spaces. Here, teaching-presence engulfs what is known as a 'headphone bubble' (Bull 2007), a space where the voice or silence permeating through the device becomes interiorized and personalized by the listener. As teaching-presence is not unidirectional, Lecturer Four's silence responds to that of her students, with her 'acting to frame her world as "intimate, known and possessed" and to structure time "into a seamless web of controlled sound and space"'(Bull 2007 in Kingsbury Downs 2021). 
The materiality or 'feltness' of Lecturer Four's students' voices and silence seeps into her headphones and into her sonic and spatial 'bubble,' causing her to respond in kind with a performance of an appropriate or 'controlled' (in)audible teachingpresence. The phrase 'seamless web' is of significance here, recalling once again the postdigital collapsing of boundaries between the physical, material, technological, digital, and social.

The inability to see teacher walking around the classroom causes their sonic presence to be felt more palpably. In this way, the teacher's silence performs teachingpresence by way of listening: a 'listening silence' (Applebaum 2016). A silence that listens is also a listening that waits without the desired interruption of the audible voice. In Lecturer Four's class, silence is felt acutely as it disrupts the safety of visual anonymity that is afforded by students being able to turn off their cameras-a concealment not possible onsite. It is a presence embodied by silence performed by the teaching-body to break this technologically assisted anonymity without requiring students to be seen but heard.

Just as the showing of one's face can expose vulnerability, so too can the teachingbody's performance of a silent presence. The absence of the teacher's incessant audible voice generates a teaching-presence defined by student-invisibility and teacher-silence. Such a teaching-presence invariably goes beyond the online space. Here, I would like to return to what Hempton (2009) says about silence being 'the presence of time.' Space may be dissected online but real time is experienced collectively. This disjuncture, not experienced onsite, is heightened online. Waiting renders the passing of time to be felt more keenly and intensely by everyone in their individual spaces. Time then is not only more present; it becomes a tangible presence that pervades across different locations.

The expectation that the teaching-body would be heard continuously during synchronous videoconferencing, and the temporary ceasing of Lecturer Four's familiar teaching-voice, is intensified and lengthened by the 'feltness' of time and its passing. 'Silences are indeed a time of breathing, of memory and resonance [and thought]. They are often described as punctuation: cuts in time, moments of ongoing spikes in the continuous flow' of talk (Edgar 1997: 311). Silence is thus also a cathexis of voice as time is given the illusion of moving at a slower pace, hence eliciting discomfort, vulnerability, and pressure on the part of students. This uneasiness can be amplified and exacerbated in an online environment as no one can be absolutely sure if the class is still 'together', what with every participant being located at different places, with some, if not most of their cameras turned off.

By this token, Lecturer Four's silence performs a temporal demarcation (Duran 2020: 90), distinct from other moments when her lesson is suffused with the comfort of teacher talk. To her, this demarcated temporality purposefully directs her students to think about what is being taught because they know that she is still conspicuously present and awaiting their responses. In turn, her intentionally engineered online silence becomes an embodied teaching-presence that is both meaningful and effective. 


\section{A Meaningful Postdigital Pedagogical Gathering of Bodies, Voices, Silences, and Machines}

Following the logic of the postdigital, 'the materiality of the digital, the embodied nature of engagement with devices, physical objects and space, and the performativity of talking to the screen' (Gourlay 2021: 58) are underscored. More specifically, the teacher's face, voice, and silence - their teaching-body-in online synchronous videoconferencing perform teaching-presence through a dynamic synthesis of the technological, corporeal, material, social, and spatio-temporal. This synthesis necessarily considers the act of teaching as a social activity that takes place in everyday life. Everyday social activity cannot be divorced from their physical, temporal, and spatial contexts. We understand each given social act as being embodied in place, space, and time.

Teaching is an everyday, repetitive, patterned social activity that takes place within and across scattered physical locations in real time. This everyday act of teaching can only be meaningfully structured and experienced when we consider all these aspects as a unified dynamic. And the only way we can effectively understand and experience this dynamic is when we take the logic of the postdigital seriously. Synchronous online teaching and the teaching-presence that is subsequently generated are thus not purely a direct replacement of that which is experienced onsite. It is a distinct postdigital gathering of human bodies, machine, physical environment, and virtual space.

The teaching-body is a physical human entity located in a physical place at a specific time. The five lecturers are not just images on the screen; they are living, breathing individuals constantly negotiating the digital space within their respective physical spaces, using their bodies to generate a presence that can be felt online and onsite. All five lecturers ensure that they are always visually and vocally present to their students when they teach via videoconferencing. The teaching-presence they perform with both face, voice, and silence is never sans the reactions and needs of their students as shown for example, from the way Lecturer Four's students appreciate her bothering to dressing up for them.

The individuality of the participants' faces and voices is performative of a pedagogical watching and listening that can only be seen, heard, and felt online. They are undeniable, unique markers of a presence that transcends the various physical colocated spaces, pervading the collective online space. They are their faces and voices; they are their teaching-bodies (Merleau-Ponty 2013). Face and voice qua the teachingbodies of the five lecturers are not only part of online teaching pedagogy; they are online teaching pedagogy. A postdigital partnership between their teaching-bodies and the technology used for teaching is required to ensure that presence is performed and sustained. This in turn impacts the way they teach and how they should use their bodies together with the accompanying technology in a pedagogically effective manner.

Such a pedagogy is essentially a postdigital, where the teaching-body performs an embodied audiovisual presence that pays special attention to affective and cognitive dimensions of online teaching. Within the digital-social context of a Zoom class, face and voice used in tandem can arguably be employed as a single entity performing the combined presence of pedagogical power and empathy within the postdigital domain.

The authorities of all five lecturers are decidedly embodied, and this is so online as much as it is onsite. By primarily using and cathecting their faces and voices to teach online, the teaching-bodies of all five participants function as sites of postdigital 
pedagogical power: They instruct and direct with their physical bodies inhabiting a physical place, together with an audio-visual technologized medium. With their faces captured on camera and framed by the screen, their voices and silences audible throughout the duration of the lesson, the lecturers become an embodied presence that seeps through the screen into the different locations inhabited by their students. Their classes are events happening in the moment, where remote locations coalesce into the single space of Zoom. Unable to see their students as a collective in a shared physical space, all five lecturers are forced to use their bodies pedagogically.

Exerting postdigital pedagogical power with their faces and voices entails the simultaneous use of empathy, not least with the changes and modulations in expression and intonation. Empathy, defined broadly as the human ability to feel emotions along with others (Batson 2009), is also that which is able to respond compassionately (Rodger and Raider-Roth 2006) to the potential locational and social-atomization, as well as the emotional and physical alienation of each student. This alienation is further materialized on screen with each student inhabiting a single square, visually and spatially apart from everyone else.

While the flatness and mechanical quality of the screen performs the 'feltness' and feeling of alienation, it can also be a conduit for empathy-as-presence. Such a presence is performed by the teaching-body's integration with the materiality of the headphone, computer camera, microphone, and the screen itself. These machines/ gadgets, together with the teaching-body are constitutive of presence, with the teacher's face-on-screen being the transmitter and distributor of empathy.

In the online space, empathy-as-presence is performed with and through the teaching-body with the latter engendering 'new dimensions [and relationship dynamics premised on the postdigital] where technologically enabled forms of identity and intimacy can be shared [and] inhabited ... from different positions in time and space. (Myers 2020: 375)

The teaching-body's individual physical self-onsite becomes a shared virtual self-online. The doubling of teaching-bodies is performative of the materiality and embodiment inherent in synchronous videoconferencing lessons. In turn, both bodies inhabit the physical as well as the technological realm where human body and machine blend into each other creating a postdigital reality. As a result, empathy qua teaching-presence is materially felt by students across their different locations both through the teacher's physical and virtual selves, of which the physical is both the source of the virtual as well as the virtual itself. ${ }^{7}$ Postdigital pedagogical power and empathy happen together, and they must be embodied, magnified, and amplified by a unifying of the teacher's body, camera, and microphone to ensure that students do not feel isolated in their remote locations.

All five lecturers utilize their faces and voices pedagogically to perform a teachingpresence that is simultaneously authoritative and empathetic through a postdigital assemblage of scattered bodies and machines. The teaching-body is performative of a postdigital

\footnotetext{
7 While my study did not garner the responses from the students, participants' efforts in considering the emotions and learning of their students must not be discounted. Distributing face and voice in response to the social dynamics of their classes is in itself a performance of empathy qua teaching-presence.
} 
teaching-presence, one that is at once part of and beyond the screen and the videoconferencing interface, providing students with a socio-material, embodied environment that is at once safe and conducive for learning. Performing teaching-presence through authority and empathy via videoconferencing is by no means an easy task. It requires teachers to consider the performativity of their own bodies and that of their students while contending with distance, remoteness, blank/black screens, and muted microphones. Teachers will need to go beyond the human-digital divide by embracing a meaningful postdigital pedagogical 'gathering' of bodies both online and onsite, in real time.

\section{Strengths, Limitations, and Future Directions}

In this paper, teachers' face and voice are sites of analysis in online synchronous videoconferencing. Unsurprisingly, face and voice are also in the focus of university websites providing tips on how teaching-presence can be achieved on videoconferencing platforms (Soisson 2020; Lee 2020; Vanderbilt University 2020).

Having interviewed only five participants, this study develops an understanding of how the teaching-body is used to perform a postdigital teaching-presence-an understanding of sufficient depth that can certainly be built on with further research. The use of Performance Studies as a theoretical lens lends a refreshing perspective from which teaching is not merely seen as a mode of communication but a doing that is part of its attendant socio-cultural structures. What is unseen must not be discounted-the rest of the teacher's body, the socio-material conditions of the space/s they inhabit, the effects of virtual backgrounds, and so on. Face and voice are parts of the larger body that inhabits an actual physical space as well as the networked space.

Such positioning can segue into a detailed study on virtual backgrounds in terms of postdigital embodied-temporal-spatial dynamics (Ritella et al. 2020). By undertaking this trajectory of research, we would also gain a better insight into how virtual backgrounds can be used as a pedagogical tool to enhance embodied teaching-presence. This calls for more research on the performativity of virtual backgrounds (as part of the larger performativity of the screen), as well as its effects on the virtual identity of the teacher. Current studies on the topic are nascent with virtual backgrounds being understood merely as a practical means to conceal the onsite spaces of students and teachers and as a marker of personality (Hacker et al. 2020; Serhan 2020).

Interviewed lecturers arrive from diverse disciplines, and four out of five interviewees are female. Such research setup is acceptable, as teacher-presence is fairly independent of taught discipline and interview questions were not centered around gender. Nevertheless, a bigger study involving more lecturers from a greater diversity of genders, sexualities, ethnicities, disciplines, and universities may offer deeper insights into how types of bodies (gendered, sexuality-based, ethicized) affect teaching-presence (Voithofer 2005). This study could also be expanded by observing and documenting selected online videoconferencing classes over a period of a semester before conducting interviews. Also, adding focus groups would allow for corroborating participants' experiences and views, making the study more empirically valid. Furthermore, interweaving Performance Studies deeper into a postdigital pedagogy of presence within education could allow for a more concrete theorization of presence. 
Understanding teaching-presence beyond the dichotomy of analog-digital enables development of new pedagogical designs. According to Fawns, 'digital education [can] encourage people to look closer at the design and practice of teaching and learning' (2019: 132) as compared to shutting down ideas or attributing certain essential or stereotypical properties to technology. Interpolating a performance approach with the teaching-body and presence in a postdigital context creates new pedagogical and curricular opportunities in which the social, cultural, technological, and material come together in the act of teaching and learning.

\section{Conclusion}

This paper indicates that the teaching-body is integral to the performing of presence in online synchronous videoconferencing. By bringing into confluence the teachingbody, presence, performance, and performativity within the postdigital context, the paper shows the importance of Performance Studies for our understanding of postdigital education. This disciplinary convergence creates what Pineau (2004) terms the 'language of possibility'. In words of Peter Brook (1968: 9): 'I can take any empty space and call it a bare stage. A man walks across this empty space whilst someone else is watching him, and this is all it is for an act of theatre to be engaged.'

Traditionally, theatre is a site where live performance takes place within a particular social context and where the actor's presence is felt through their voice, silence, and body. This presence penetrates the space of the audience, affecting them emotionally and physically. By this token, theatre performance is at the intersections between the material, corporeal, and social. It is an event that happens in a given place and time, where spatio-temporal, bodies, sound, and silence come into a complex confluence.

Brook's (1968) empty space is not characterized by pejorative connotations of emptiness or void. Rather, it is one where the reciprocal acts of doing, looking, and listening are paramount to the act of creation. When such a confluence is engendered, something happens out of nothing; somewhere happens out of nowhere. Empty space is now inhabited, filled with mutually engaged looking and listening bodies.

Similarities between theatre and teaching can be approached by revisiting the 'empty space' where Lecturers Two and Three feel unseen and unheard. In this space, Lecturers Two and Three find the act watching and listening uneven, inconsistent, and uncertain. Brook's (1968) notion of the empty space however presents a very different perspective and can potentially transform these experiences. By adopting the language and space of possibility as per Pineau (2004) and Brook (1968), the idea of theatre and performance can be extended to the online videoconferencing class where the 'empty space' of small, black screens is suffused and engaged by the visual and/or aural presence of the performing teaching-body, synchronously or 'live,' in real time. Uncertain empty space then becomes a postdigital space filled with opportunity.

Understanding presence and embodied teaching in a postdigital context through the lens of performance and performativity debunks the naïve misconception that 'cyberlearning is, indeed, disembodied' (Land 2004: 530). Such change in mindset could allow for development of richer postdigital teaching and learning, online and offline. 


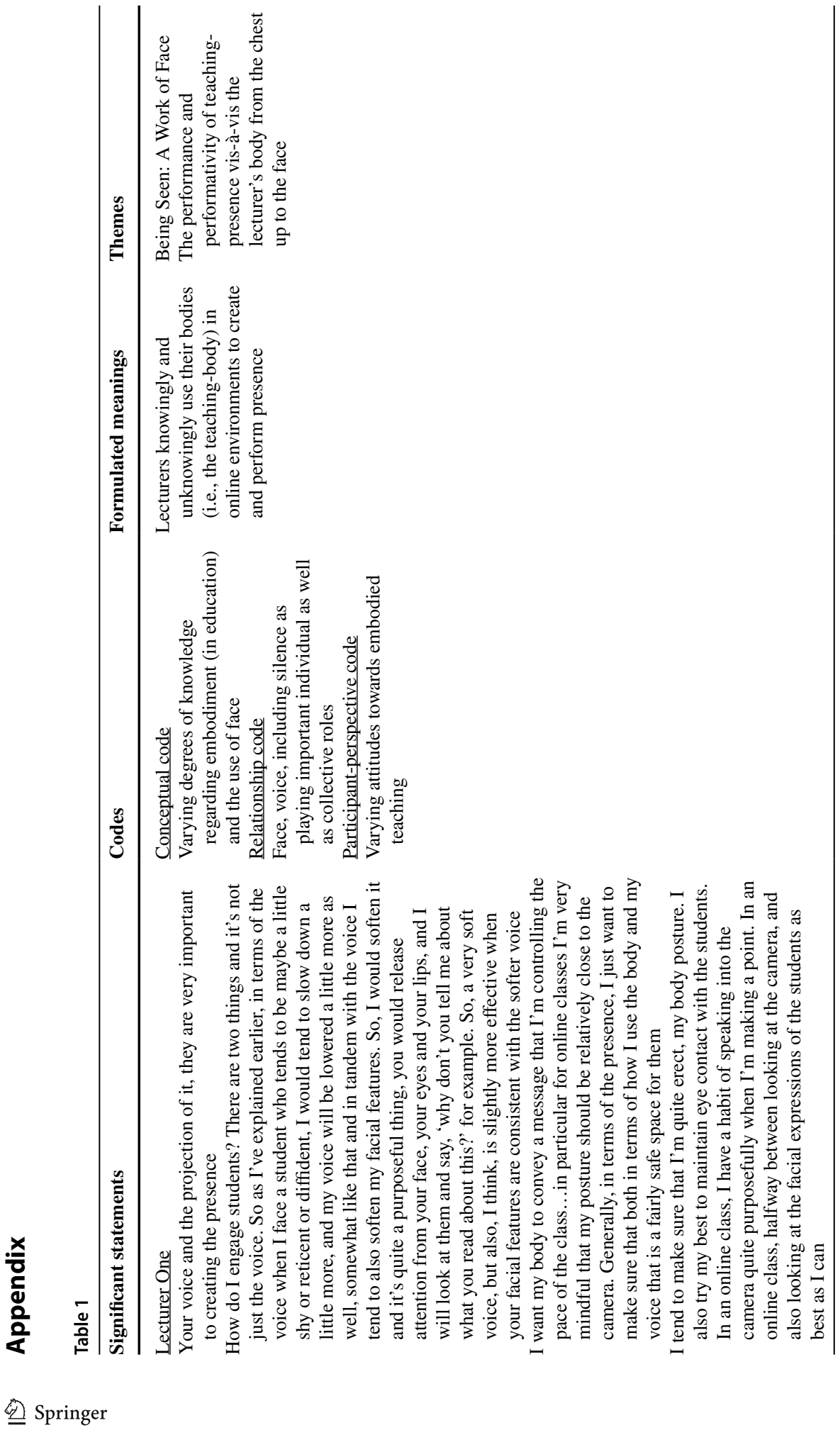




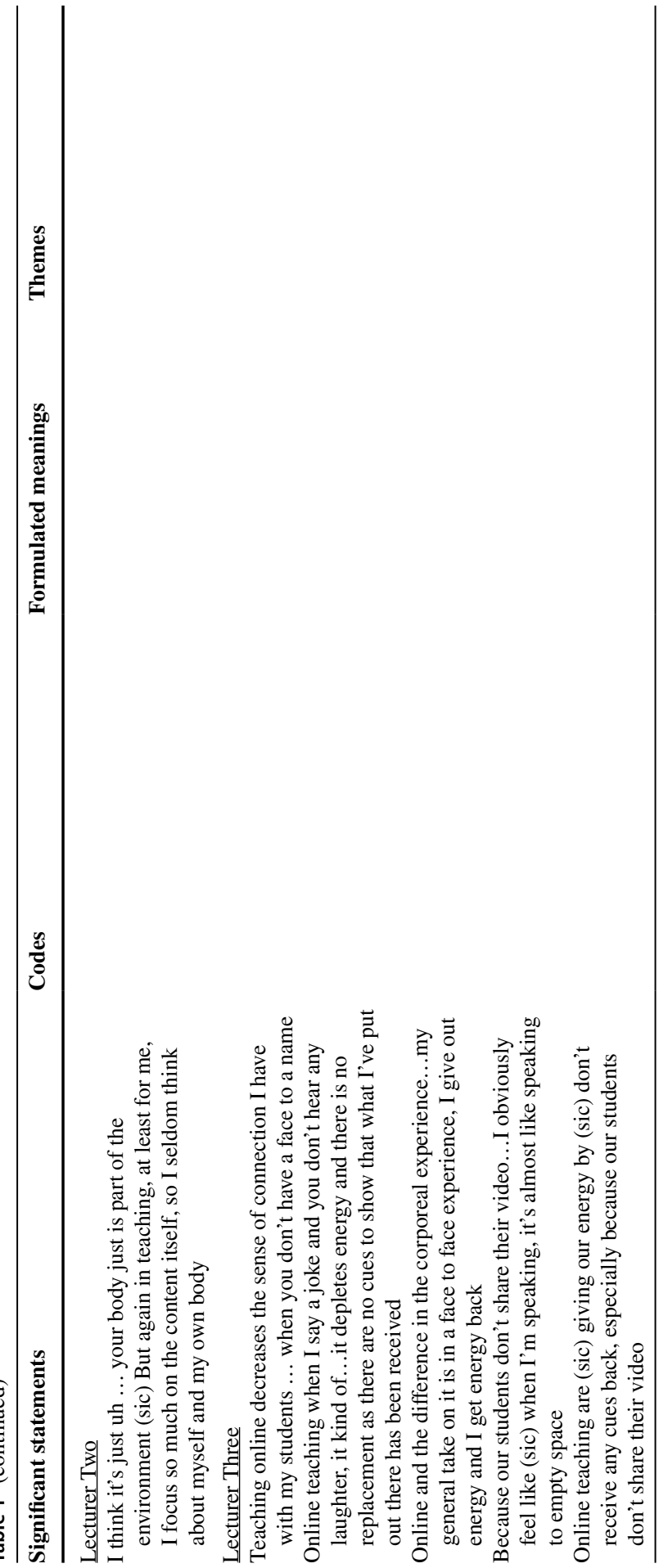




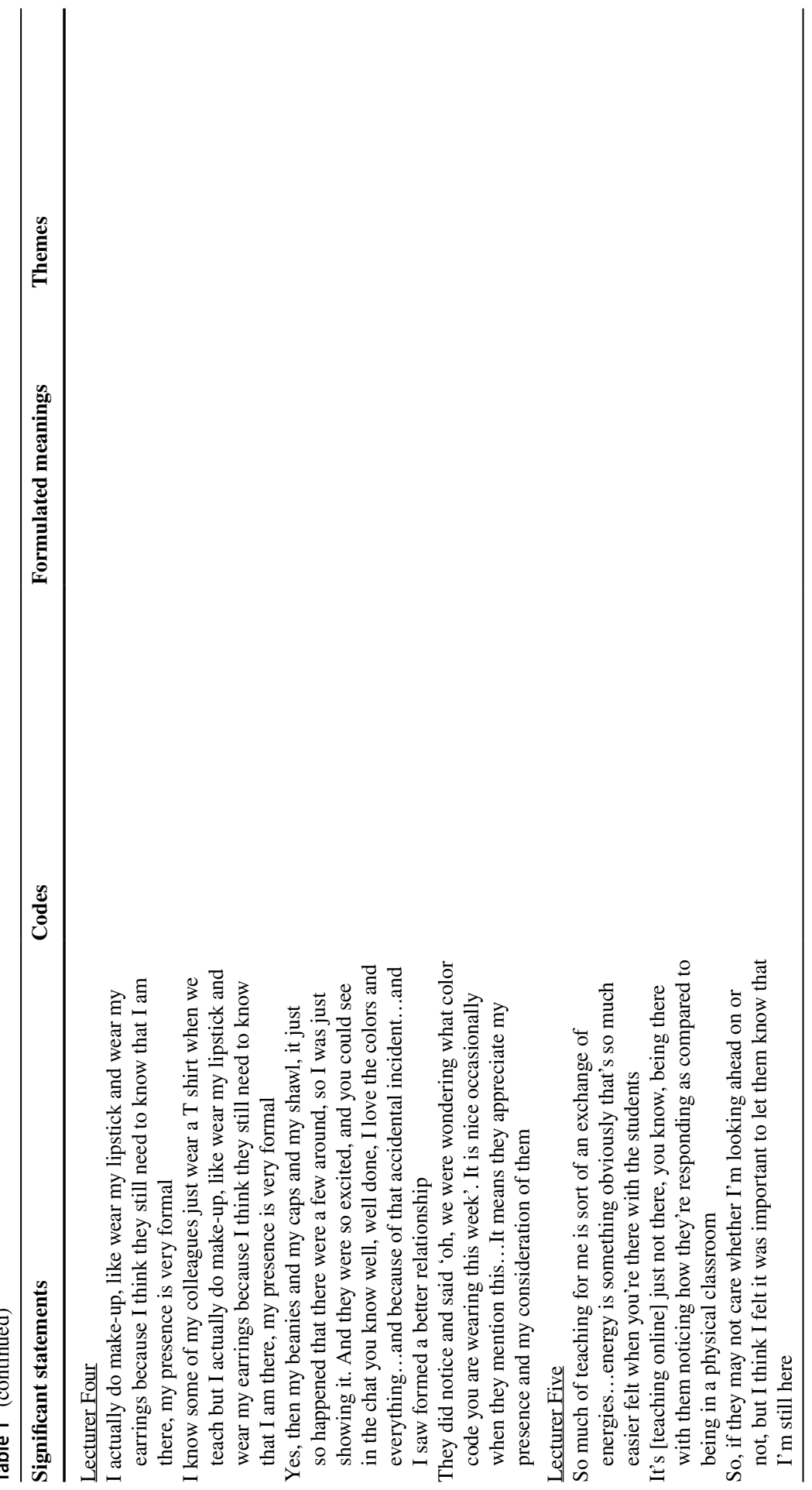




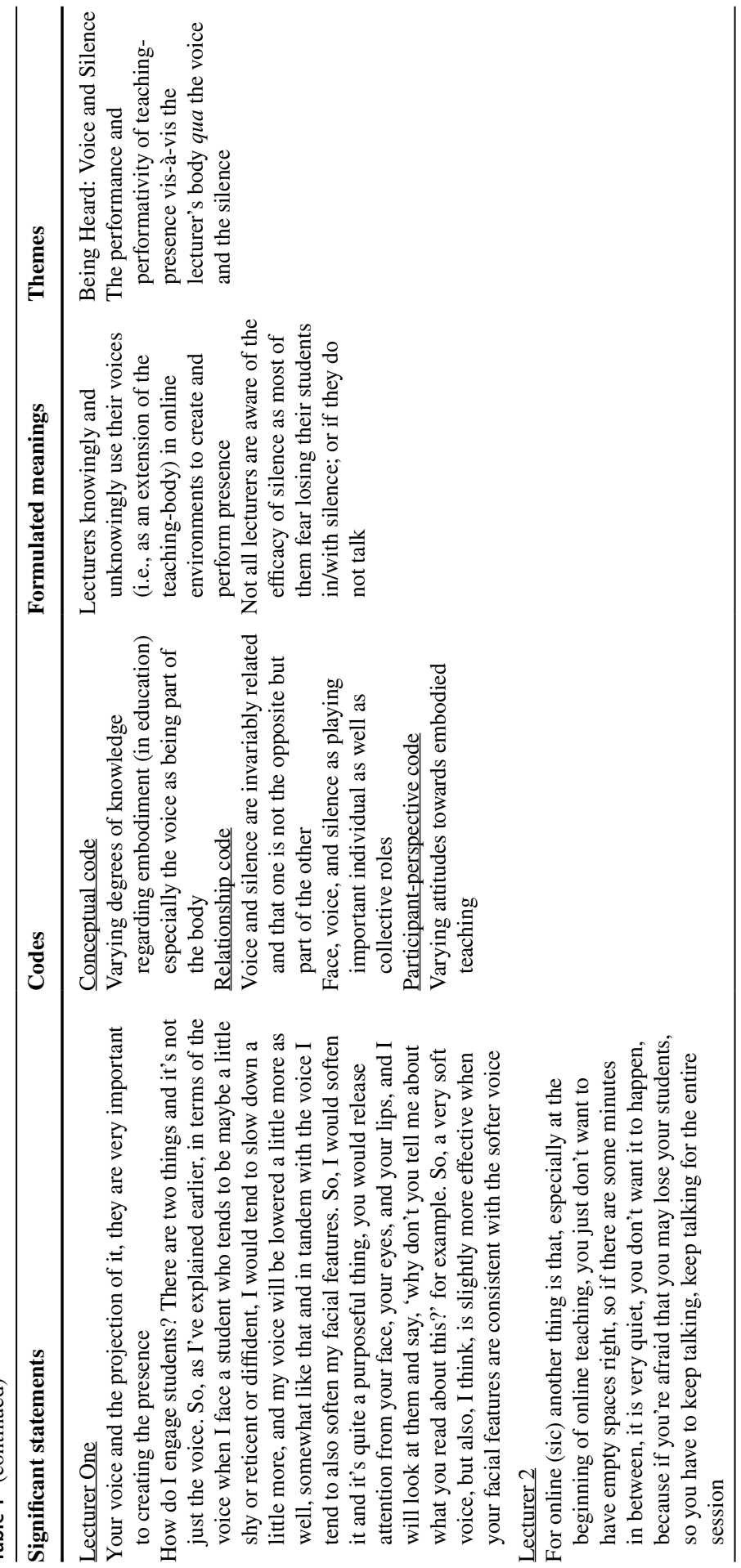




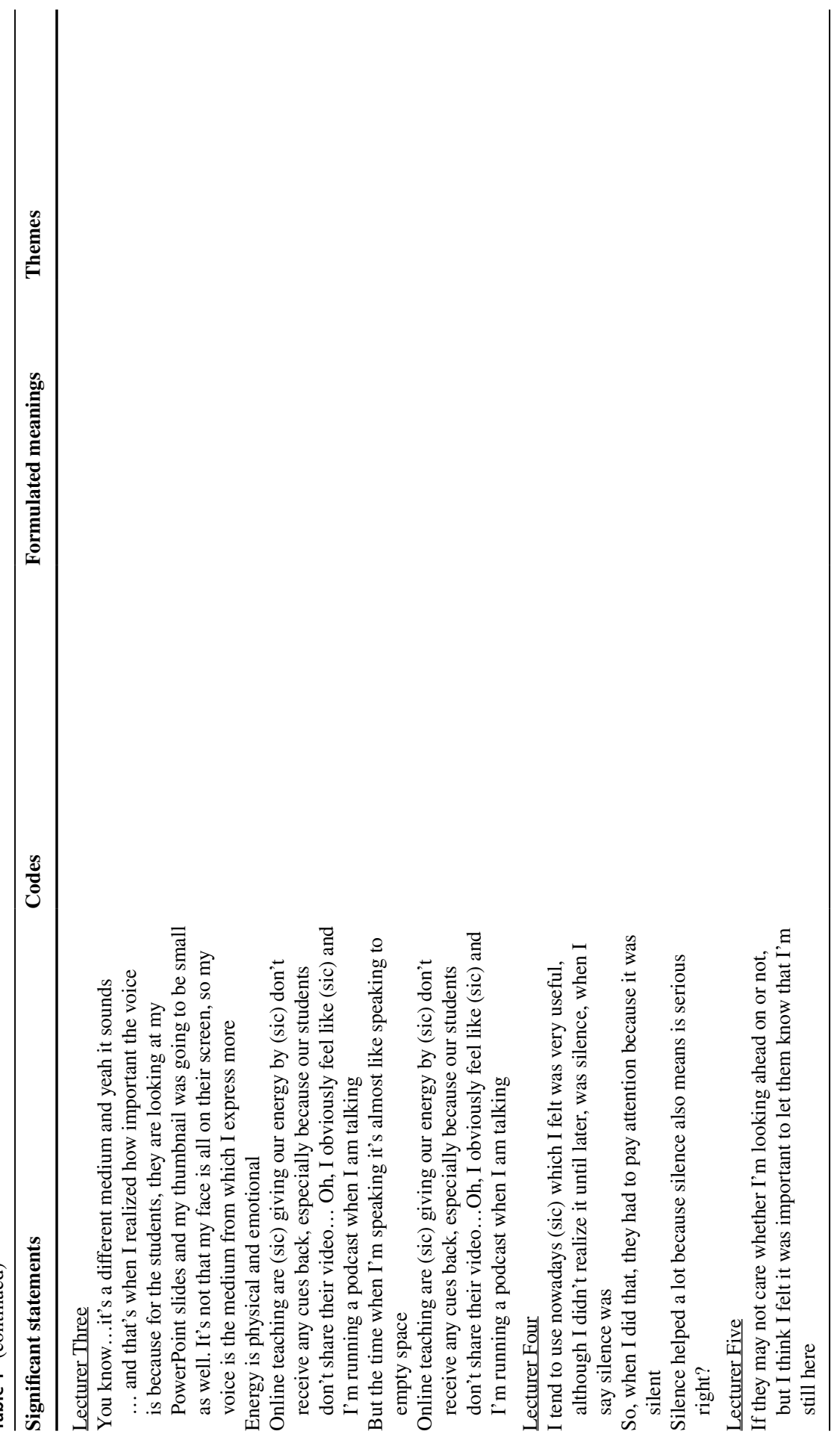


Availability of Data and Materials Interviews with participants will be kept anonymous. Should the need arise where the sharing of their full interviews be made public, official consent would have to be sought.

\section{Declarations}

Ethics Approval and Consent to Participate The author declares that qualitative research involving the interviewing of 5 research participants has been approved by the University's Institutional Review Board (IRB). IRB documents are available should the need to submit them arise. Participants are lecturers at a university in Singapore and do not belong to any vulnerable group.

Consent for Publication The author obtained the official consent of all research participants to have their interview material used anonymously. Documents are available should the need to submit them arise.

Conflict of Interest The author declares no competing interests.

\section{References}

Alerby, E., Hagström, E., \& Westman, S. (2014). The Embodied Classroom: A Phenomenological Discussion of the Body and the Room. Journal of Pedagogy, 1, 11-23. https://doi.org/10.2478/ jped-2014-0001.

Alexander, B. K., Anderson, G. L., \& Gallegos, B. P. (2004). Introduction. In B. K. Alexander, G. L. Anderson, \& B. P. Gallegos (Eds.), Performance Theories in Education: Power, Pedagogy, and the Politics of Identity (pp. 1-14). Abingdon and New York: Routledge.

Anderson, T., Rourke, L., Garrison, D. R., \& Archer, W. (2001). Assessing Teaching Presence in a Computer Conferencing Context. Journal of Asynchronous Learning Networks, 5(2), 2-17. https://doi. org/10.24059/olj.v5i2.1875.

Applebaum, B. (2016). "Listening Silence" and Its Discursive Effect. Educational Theory, 66(3), 389404. https://doi.org/10.1111/edth.12172.

Assor, A., Kaplan, H., Feinberg, O., \& Tal, K. (2009). Combining Vision With Voice: A Learning and Implementation Structure Promoting Teachers' Internalization of Practices Based on Self-determination Theory. Theory and Research in Education, 7(2), 234-243. https://doi.org/10.1177/ 1477878509104328.

Austin, J. L. (1979). Performative Utterances. In J. O. Urmson \& G. J. Warnock (Eds.), Philosophical Papers (pp. 233-252). New York: Oxford University Press.

Barbour, K. (2004). Embodied Ways of Knowing. Waikato Journal of Education, 10, 227-238.

Batson, C. D. (2009). These Things Called Empathy: Eight Related but Distinct Phenomena. In J. Decety \& W. Ickes (Eds.), The Social Neuroscience of Empathy (pp. 3-15). Cambridge, MA: MIT Press. https://doi.org/10.7551/mitpress/9780262012973.003.0002.

Bayne, S. (2004). Smoothness and Striation in Digital Learning Spaces. E-learning, 1(2), 302316. https://doi.org/10.2304/elea.2004.1.2.6.

Bayne, S., \& Jandrić, P. (2017). From Anthropocentric Humanism to Critical Posthumanism in Digital Education. Knowledge Cultures, 5(2), 197-216. http://dx.doi.org.libproxy1.nus.edu.sg/10.22381/ KC52201712.

Biocca, F., Harms, C., \& Burgoon, J. K. (2003). Towards A More Robust Theory and Measure of Social Presence: Review and Suggested Criteria. Presence Teleoperators \& Virtual Environments, 12(5), 456-480. https://doi.org/10.1162/105474603322761270.

Bolldén, K. (2014). Teachers' Embodied Presence in Online Teaching Practices. Studies in Continuing Education, 38(1), 1-15. https://doi.org/10.1080/0158037X.2014.988701.

Brinkmann, S., \& Kvale, S. (2015). Interviews: Learning the Craft of Qualitative Research Interviewing. $3^{\text {rd }}$ Edition. London: Sage.

Brook, P. (1968). The Empty Space. New York: Simon \& Schuster.

Bull, M. (2007). Sound Moves: iPod Culture and Urban Experience. Abingdon: Routledge.

Burns, U. (2009). The Concept of Performativity in Narratology. European Journal of English Studies, 13(1), 93-108. https://doi.org/10.1080/13825570802708204. 
Campbell, P. (2000). The Body in Performance. London and New York: Routledge.

Casey, R. L., \& Kroth, M. (2013). Learning to Develop Presence Online: Experienced Faculty Perspectives. Journal of Adult Education, 42(2), 104-110.

Conroy, C. (2010). Theatre and The Body. London: Routledge.

Clarke, E., \& Davidson, J. (1998). The Body in Performance. In W. Thomas (Ed.), Composition, Performance, Reception Studies in the Creative Process in Music (pp. 74-92). London and New York: Routledge.

Dewey, J. (1961). Democracy and Education: An Introduction to the Philosophy of Education. London: Palgrave Macmillan.

Dewey, J, (2000). Experience and Nature. New York: Dover Publications.

Downs, J. K. (2021). Acoustic Territories of the Body: Headphone Listening, Embodied Space, and the Phenomenology of Sonic Homeliness. Journal of Sonic Studies, 21. https://www.researchcatalogue. net/view/1260374/1260375. Accessed 11 January 2022.

Dreyfus, H. (2001). On the Internet: Thinking in Action. $2^{\text {nd }}$ Edition. London and New York: Routledge.

Duran, L. (2020). Distance Learners' Experiences of Silence Online: A Phenomenological Inquiry. The International Review of Research in Open and Distributed Learning, 21(1), 82-98. https://doi.org/ 10.19173/irrodl.v20i5.4538.

Edgar, A. (1997). Music and Silence. In A. Jaworski (Ed.), Silence: Interdisciplinary Perspectives (pp. 311-328). Berlin: Mouton de Gruyter.

Edwards-Groves, C. (2017). Teaching and Learning as Social Interaction: Salience and Relevance in Classroom Lesson Practices. In P. Grootenboer, C. Edwards-Groves, \& S. Choy (Eds.), Practice Theory Perspectives on Pedagogy and Education: Praxis, Diversity and Contestation (pp. 191231). Singapore: Springer. https://doi.org/10.1007/978-981-10-3130-4_10.

Ellsworth, E. (2004). Places of Learning: Media, Architecture, Pedagogy. New York: Routledge. https:// doi.org/10.4324/9780203020920.

Evans, M. (2019). Performance, Movement and the Body: Theatre and Performance Practices. London: Palgrave Macmillan.

Fawns, T. (2019). Postdigital Education in Design and Practice. Postdigital Science and Education, 1(1), 132-145. https://doi.org/10.1007/s42438-018-0021-8.

Fawns, T., Aitken, G., \& Jones, D. (2019). Online Learning as Embodied, Socially Meaningful Experience. Postdigital Science and Education, 1(2), 293-297. https://doi.org/10.1007/ s42438-019-00048-9.

Fawns, T., \& O'Shea, C. (2019). Evaluative judgement of working practices: Reconfiguring Assessment to Support Student Adaptability and Agency Across Complex Settings. Italian Journal of Educational Technology, 27(1), 5-18. https://doi.org/10.17471/2499-4324/1027.

Francesconi, D., \& Tarozzi, M. (2012). Embodied Education: A Convergence of Phenomenological Pedagogy and Embodiment. Studia Phaenomenologica, 12, 263-288. https://doi.org/10.7761/SP.12.263.

Freiler, T. J. (2008). Learning Through the Body. New Directions for Adult and Continuing Education, 119, 37-47. https://doi.org/10.1002/ace.304.

Glenberg, A. M. (2009). Embodiment for Education. In P. Calvo \& A. Gomila (Eds.), Handbook of Cognitive Science: An Embodied Approach (pp. 355-372). Elsevier.

Goffman, E. (1967). On Face-Work. In E. Goffman (Ed.), Interaction Ritual: Essays in Face-to-Face Behavior (pp. 5-45). New York: Doubleday.

Gourlay, L. (2020). Quarantined, Sequestered, Closed: Theorising Academic Bodies Under Covid19 Lockdown. Postdigital Science and Education, 2(3), 791-811. https://doi.org/10.1007/ s42438-020-00193-6.

Gourlay, L. (2021). There Is No 'Virtual Learning': The Materiality of Digital Education. Journal of New Approaches in Educational Research, 10(1), 57-66. https://doi.org/10.7821/naer.2021.1.649.

Green, G. L. (1999). The Return of the Body: Performance Art and Art Education, Art Education, 52(1), 6-12. https://doi.org/10.1080/00043125.1999.11652187.

Guest, G., MacQueen, K. M., \& Namey, E. E. (2012). Applied thematic analysis. SAGE. https://doi.org/ $10.4135 / 9781483384436$.

Hacker, J., Vom Brocke, J., Handali, J., Otto, M., \& Schneider, J. (2020). Virtually In This Together: How Web-conferencing Systems Enabled a New Virtual Togetherness During the COVID-19 Crisis. European Journal of Information Systems, 29(5), 563-584. https://doi.org/10.1080/0960085x. 2020.1814680 .

Hayles, K. (2002). Writing Machines. Cambridge, MA: MIT University Press. https://doi.org/10.7551/ mitpress/7328.001.0001. 
Hempton, G. (2009). One Square Inch of Silence: One Man's Search for Silence in a Noisy World. New York: Simon \& Schuster.

Hernandez, H. B., \& Dringus, L. P. (2021). The Embodiment of Discovery: An Adapted Framework for Qualitative Analysis of Lived Experiences. The Qualitative Report, 26(6), 1736-1761. https://doi. org/10.46743/2160-3715/2021.4748.

Hine, C. (2015). Internet Ethnography for the Internet: Embedded, Embodied and Everyday. London and New York: Routledge.

Husserl, E. (1983). Ideas Pertaining to a Pure Phenomenology and to a Phenomenological Philosophy. Trans. F. Kersten. Leiden: Martinus Nijhoff.

Ijsselsteijn, W., \& Riva, G. (2003). Being There: The Experience of Presence in Mediated Environments. In G. Riva, F. Davide, \& W. A. Ijsselsteijn (Eds.), Being there: Concepts, Effects and Measurements of User Presence in Synthetic Environments (pp. 3-16). Amsterdam: IOS Press.

Jandrić, P., \& Hayes, S. (2020). Postdigital We-Learn. Studies in Philosophy and Education, 39, 85-297. https://doi.org/10.1007/s11217-020-09711-2.

Jarvis, L. (2019). Immersive Embodiment: Theatres of Mislocalized Sensation. London: Palgrave Macmillan.

Jonassen, D. H. (2000). Transforming Learning with Technology: Beyond Modernism and PostModernism or Whoever Controls the Technology Creates the Reality. Educational Technology, 40(2), 21-25. http://dx.doi.org/10.1007/978-94-6209-269-3_7.

Kelland, J. H. (2006). Theorizing the Body: Developing a Framework for Understanding the Body in Online Learning Environments. Adult Education Research Conference (AERC) 2017, Minneapolis, USA. https://newprairiepress.org/aerc/2006/papers/36. Accessed 11 January 2021.

Kennette, L. N., \& Redd, B. R. (2015). Instructor Presence Helps Bridge the Gap between Online and On-Campus Learning. College Quarterly, 18(4).

Koivunen, T. (2007). Embodied Voice and Embodied Differences in Call Centre Work [Paper Presentation]. INTER: A European Cultural Studies Conference in Sweden, Norrköping. https://www. researchgate.net/publication/229019934_Embodied_voice_and_embodied_differences_in_call_ centre_work\#fullTextFileContent. Accessed 11 January 2021.

Land, R. (2004). Issues of Embodiment and Risk in Online Learning. In R. Atkinson, C., McBeath, D. Jonas-Dwyer, \& R. Phillips (Eds.), Beyond the Comfort Zone: Proceedings of the $21^{\text {st }}$ ASCILITE Conference (pp. 530-538). http://www.ascilite.org.au/conferences/perth04/procs/land.html. Accessed 11 January 2021.

Lawy, J. R. (2017). Theorizing Voice: Performativity, Politics and Listening. Anthropological Theory, 17(2), 192-215. https://doi.org/10.1177/1463499617713138.

Lee, G. L. (2020). Va-va Vroom in Zoom - Establishing an Online Teacher-Presence in the Zoom Classroom. Singapore: National University of Singapore. https://blog.nus.edu.sg/teachingconnections/ 2020/05/06/va-va-vroom-in-zoom-establishing-an-online-teacher-presence-in-the-zoom-classroom/. Accessed 1 November 2021.

Lee, P. (2014). Singaporeans 'more doers than talkers', say experts. The Straits Times, 5 April. https:// www.straitstimes.com/singapore/singaporeans-more-doers-than-talkers-say-experts. Accessed 29 July 2021.

Lehman, R. M., \& Conceição, S. C. O. (2010). Creating a Sense of Presence in Online Teaching: How to "Be There" for Distance Learners. San Francisco, CA: Jossey-Bass.

Leigh, J. (Ed.). (2019). Conversations on Embodiment Across Higher Education: Teaching, Practice and Research. London and New York: Routledge.

Lochmiller, C. R. (2021). Conducting Thematic Analysis with Qualitative Data. The Qualitative Report, 26(6), 2029-2044. https://doi.org/10.46743/2160-3715/2021.5008.

Lyberg Ảhlander, V., Pelegrín García, D., Whitling, S., Rydell, R., \& Löfqvist, A. (2014). Teachers' Voice Use in Teaching Environments: A Field Study Using Ambulatory Phonation Monitor. Journal of Voice, 28(6), 841.e5. https://doi.org/10.1016/j.jvoice.2014.03.006.

Mardahl-Hansen, T. (2018). Teaching as a Social Practice. Nordic Psychology, 71(1), 3-16. https://doi. org/10.1080/19012276.2018.1457451.

McAllister-Viel, T. (2016). The Role of 'Presence' In Training Actors' Voices. Theatre, Dance and Performance Training, 7(3), 438-452. https://doi.org/10.1080/19443927.2016.1217265.

McDonald, J. (1986). Raising the Teacher's Voice and the Ironic Role of Theory. Harvard Educational Review, 56(4), 355-379. https://doi.org/10.17763/haer.56.4.93q80781768635m3.

Merleau-Ponty, M. (2013). The Phenomenology of Perception. London and New York: Routledge. 
Munoz, C., \& Towner, T. (2009). Opening Facebook: How to Use Facebook in the College Classroom. In I. Gibson, R. Weber, K. McFerrin, R. Carlsen, \& D. Willis (Eds.), Proceedings of SITE 2009--Society for Information Technology \& Teacher Education International Conference (pp. 2623-2627). Charleston, SC: Association for the Advancement of Computing in Education (AACE). https://www.learntechlib.org/primary/p/31031/. Accessed 1 November 2021.

Muthuprasada, T., Aiswaryab, S., Adityaa, K. S., \& Jhaa, G. K. (2021). Students' perception and preference for online education in India during COVID -19 pandemic. Social Sciences \& Humanities Open, 3(1), 1-11. https://doi.org/10.1016/j.ssaho.2020.100101.

Myers, M. (2020). 'The Waves Carve Their Own Desires': The Affects and Agencies of Intramedial Performance. Research in Drama Education: The Journal of Applied Theatre and Performance, 25(3), 364-377. https://doi.org/10.1080/13569783.2020.1766952.

Natanson, M. (Ed.). (1973). Phenomenology and the Social Sciences. Evanston, IL: Northwestern University Press.

Öztok, M., \& Brett, C. (2011). Social Presence and Online Learning: A review of the Research. The Journal of Distance Education, 25(3), 1-10.

ParaTheatrical ReSearch (2008). The Embodied Voice: Interview with Sylvi Alli. https://www.paratheatrical. com/voiceinterview.html. Accessed 6 June 2021.

Perry, M., \& Medina, C. (2011). Embodiment and Performance in Pedagogy Research: Investigating the Possibility of the Body in Curriculum Experience. Journal of Curriculum Theorizing, 27(3), 63-75.

Pettman, D. (2017). Sonic Intimacy: Voice, Species, Technics (Or, How to Listen to the World). Stanford, CA: Stanford University Press.

Pineau, E. L. (2004). Teaching Is Performance: Reconceptualizing a Problematic Metaphor. In B. K. Alexander, G. L. Anderson, \& B. P. Gallegos (Eds.), Performance Theories in Education: Power, Pedagogy, and the Politics of Identity (pp. 15-49). New York and London: Routledge.

Pollock, D. (1998). Performing Writing. In P. Phelan \& J. Lane (Eds.), The Ends of Performance (pp. 73-103). New York: New York University Press.

Pollock, D. (2007). The Performative "I." Cultural Studies $\leftrightarrow$ Critical Methodologies, 7(3), 239-255. https://doi.org/10.1177/1532708606288649.

Preisman, K. (2014). Teaching Presence in Online Education: From the Instructor's Point-of-View. Journal of Asynchronous Learning Network, 18. https://doi.org/10.24059/olj.v18i3.446.

Probyn, E. (2004). Teaching Bodies: Affects in the Classroom. Body \& Society, 10(21), 21-43. https://doi. org/10.1177/1357034X04047854.

Rigg, C. (2018). Somatic learning: Bringing the Body into Critical Reflection. Management Learning, 49(2), 150-167. https://doi.org/10.1177/1350507617729973.

Ritella, G., Rajala, A., \& Renshaw, P. (2020). Using Chronotope to Research the Space-Time Relations of Learning and Education: Dimensions of the Unit of Analysis. Learning, Culture and Social Interaction. https://doi.org/10.1016/j.1csi.2020.100381.

Rodenberg, P. (2002). The Actor Speaks: Voice and the Performer. New York: St. Martin's Press.

Rodgers, C. R., \& Raider-Roth, M. B. (2006). Presence in Teaching. Teachers and Teaching, 12(3), 265287. https://doi.org/10.1080/13450600500467548.

Rosati-Peterson, G. L., Piro, J. S., Straub, C., \& O'Callaghan, C. (2021). A Nonverbal Immediacy Treatment with Pre-Service Teachers Using Mixed Reality Simulations. Cogent Education, 8(1), 1882114. https://doi.org/10.1080/2331186x.2021.1882114.

Rubin, H. J., \& Rubin, I. S. (1995). Qualitative Interviewing: The Art of Hearing Data. London: Sage.

Schechner, R. (2007). Performance Studies: The Broad Spectrum Approach. In H. Bial (Ed.), The Performance Studies Reader (pp. 5-6). London: Routledge.

Schlichter, A., \& Eidsheim, N.S. (2014). Introduction: Voice Matters. Postmodern Culture, 24(3). https:// doi.org/10.1353/pmc.2014.0012 .

Selwyn, N. (2012). Social Media in Higher Education. The Europa World of Learning, 1(3), 1-10.

Selwyn, N. (2016). Is Technology Good for Education? London: Polity.

Serhan, D. (2020). Transitioning from face-to-face to remote learning: Students' attitudes and perceptions of using Zoom during COVID-19 Pandemic. International Journal of Technology in Education and Science, 4(4), 335-342. https://doi.org/10.46328/ijtes.v4i4.148.

Shea, P., Li, C. S., Swan, K., \& Pickett, A. (2005). Developing Learning Community in Online Asynchronous College Courses: The Role of Teaching Presence. Journal of Asynchronous Learning Networks, 9(4), 59-82. http://dx.doi.org/10.24059/olj.v9i4.1779.

Shilling, C. (2012). The Body and Social Theory. London: SAGE.

Shilling, C. (2016). The Body: A Very Short Introduction. New York: Oxford University Press. 
Shilling, C. (2020). Embodiment. In P. Kivisto (Ed.), The Cambridge Handbook of Social Theory (pp. 249-271). Cambridge: Cambridge University Press. https://doi.org/10.1017/9781316677452.014.

Sime, J.-A., \& Themelis, C. (2020). Educators' Perspectives on Transmedia Identity Management: Redefining Tele-teacher Presence. Distance Education, 41(1), 70-85. https://doi.org/10.1080/01587919. 2020.1727292.

Stacey, E. (2002). Social Presence Online: Networking Learners at a Distance. In D. Watson, \& J. Andersen (Eds.), Networking the Learner. WCCE 2001. IFIP - The International Federation for Information Processing, vol 89 (pp. 39-48). Boston, MA: Springer. https://doi.org/10.1007/ 978-0-387-35596-2_4.

Soisson, A. (2020). Ways to Engage Students when Teaching Remotely with Zoom. https://sites.tufts. edu/teaching/2020/03/17/ways-to-engage-students-when-teaching-remotely-with-zoom/. Accessed 13 May 2021.

Sundén, J. (2003). Material Virtualities: Approaching Online Textual Embodiment. New York: Peter Lang.

Suzuki, T. (2015). Culture is the Body: The Theatre Writings of Tadashi Suzuki. Trans. K. Stelle. New York: Theatre Communications Group.

Tani, M. (2004). Quiet, But Only in Class: Reviewing the In-Class Participation of Asian Students. Higher Education Research and Development Society of Australasia Conference 2004. https:// conference.herdsa.org.au/2005/pdf/non_refereed/030.pdf. Accessed 11 January 2022.

Tiberius, R., \& Billson, J. M. (1991). The Social Context of Teaching and Learning. New Directions for Teaching and Learning, 45, 67-86. https://doi.org/10.1002/tl.37219914509.

Tobin, J. A., \& Tisdell, E. J. (2015). "I Know Down to My Ribs": A Narrative Research Study on the Embodied Adult Learning of Creative Writers. Adult Education Quarterly, 65(3), 215-231. https:// doi.org/10.1177/0741713615574901.

Vaismoradi, M., Jones, J., Turunen, H., \& Snelgrove, S. (2016). Theme Development in Qualitative Content Analysis and Thematic Analysis. Journal of Nursing Education and Practice, 6(5), 100-110. https://doi.org/10.5430/jnep.v6n5p100.

Vanderbilt University (2020). Who's Zooming Who? Best Practices For Zoom and Other Video Meetings. https://www.vumc.org/coronavirus/latest-news/whos-zooming-who-best-practices-zoom-andother-video-meetings. Accessed 1 November 2021.

Voithofer, R. (2005). Nomadic Epistemologies and Performative Pedagogies in Online Education. Educational Theory, 52, 479-494. https://doi.org/10.1111/j.1741-5446.2002.00479.x.

Walters, P., \& Kop, R. (2009). Heidegger, Digital Technology, and Postmodern Education. Bulletin of Science, Technology \& Society, 29(4), 278-286. https://doi.org/10.1177/0270467609336305.

Ward, D. (2018). What's Lacking in Online Learning? Dreyfus, Merleau-Ponty and Bodily Affective Understanding. Journal of Philosophy of Education, 52(3), 428-450. https://doi.org/10.1111/14679752.12305.

Warren, C. A. B., \& Karner, T. X. (2015). Discovering Qualitative Methods: Ethnography, Interviews, Documents, and Images. New York: Oxford University Press.

Publisher's Note Springer Nature remains neutral with regard to jurisdictional claims in published maps and institutional affiliations. 